\title{
Implementing computer education: The role of the primary principal
}

\author{
John Schiller \\ University of Newcastle
}

The introduction of computers into schools has placed unique pressures on school principals to implement change. Therefore, knowledge of how principals effectively manage staff and pupil use of computers is essential. This paper reports on a study to investigate implementation of Computer Education. As an innovation in the elementary school, introduction and use of computers was not a requirement of the NSW Department of School Education, but depended on school-based decision making and initiatives. A combination of quantitative and qualitative data-gathering procedures was used in a selected sample of six urban, elementary schools in one educational region to investigate the relationship between the interventions of principals and implementation success of Computer Education, which was determined through use of multiple Concerns-Based Adoption Model (CBAM) diagnostic devices: Stages of Concern, Levels of Use and Innovation Configuration. Interventions made by principals and other key change facilitators were documented in self-report diaries and from regular semi-focussed interviews. Interventions were analysed according to an Intervention Taxonomy and compared across schools.

The study demonstrated that principals are key figures in successful implementation of Computer Education, because of the number and type of their interventions. In particular, those interventions of the principal, which have a monitoring and evaluative function, appear to be influential in determining the degree of implementation of Computer Education. Implementation success was greatest at schools where the principal demonstrated an 'initiator' change facilitation style as compared to a 'manager' or 'responder' style. The 'responder' change facilitation style was associated with least success in implementation of Computer Education. The study also demonstrated that interventions of other school-based change facilitators influenced implementation. Formation of a change facilitation team was important in successful implementation of Computer Education. 
School principals are faced with a dilemma: maintain the status quo, or promote change. Research on the role of the principal in change has suggested various possibilities. One conclusion is that the principal's role as an instructional leader is a key factor in the process of educational change/school improvement (Bossert, Dwyer, Rowan \& Lee, 1982; Fullan 1985; Leithwood \& Montgomery, 1982; Persell \& Cookson, 1982; Purkey \& Smith, 1983). A counter viewpoint is that the principal's day is too fragmented and varied, and encounters are too brief to enable them to be effective instructional leaders (Duignan, 1984; Kmetz \& Willower 1982; Morris, Crowson, Porter-Gehre \& Hurwitz 1982; Peterson, 1978; Willis, 1980). Although school improvement is complex, successful implementation of change can take place through the efforts of the principal working with and through others (Duke, 1987; Fullan, 1982; Hall \& Hord, 1987; Hallinger \& Murphy, 1985).

In Australian primary (elementary) schools, a recent trend away from school-based curriculum development (SBCD) to a more centralised, state controlled curriculum, has resulted in key players in curriculum change adopting different roles. The curriculum is implemented according to local need, but within a framework of set syllabus and guidelines, often determined by a state curriculum project team and implemented through state curriculum coordination groups. At the school level, however, implementation of curriculum change is usually a delegated responsibility of the principal, thereby ensuring that he or she is expected to adopt a change facilitation role. What, then, is the reality of the primary principal as an agent of change?

\section{Implementing Computer Education}

An example of school principals as change facilitators in implementation of change can be seen in a recent curriculum innovation in New South Wales. In NSW, Computer Education has been adopted, at the state level, as a new curriculum area for primary schools. Implementation however, was dependent on regional and local initiatives, assisted by State level support/ guidelines documents. In implementing Computer Education, not only were teachers faced with teaching new concepts and skills, they were also confronted with unfamiliar technology, and children who may have had more experience with, and a greater knowledge of, computers. With the Federal Government's 1984 initiative (Commonwealth Schools Commission, 1984) to promote Computer Education in every Australian school, the decision faced by school personnel was not to decide whether to become involved in Computer Education, but when, and in what way. For the school principal, this situation posed questions such as: 
- What actions should be taken at the school level to implement Computer Education?

- Who does what to whom and for what purpose?

- What are the consequences?

Information was available regarding a rationale for Computer Education (Commonwealth Schools Commission, 1984). Articles on setting up Computer Education programs in schools were plentiful. Data on the availability, type and usage of computers in schools had been documented (Anderson, 1984; Baume et al, 1986; Fitzgerald, Hattie \& Hughes, 1985) but description of implementation of Computer Education was scarce; particularly concerning the roles played by school-level personnel. MacKay (1983), in describing three case studies of computer use in primary schools, hinted at the importance of "high profile" styles of principals in implementing Computer Education. Another study of Computer Education in selected NSW primary schools found a significant relationship among more task-oriented principals and the degree of implementation of computer education by teachers (Carbines, 1986).

The literature, however, provides little insight into actions within a school, over time, in relation to implementation of Computer Education. A method of gaining this insight is available in the Concerns-Based Adoption Model (CBAM), a conceptual framework incorporating research techniques and methodologies developed at the Research and Development Centre for Teacher Education (RDTCE) at Austin, Texas. Assumptions underlying this approach to change, and the results of over fifteen years of intensive research, have been fully documented (Hall \& Hord, 1987). Recent studies, which used this model to investigate the change facilitation style of school leaders (Hall, Rutherford, Hord \& Huling-Austin, 1984), and interventions used in curriculum implementation (Hord \& Huling-Austin, 1986), provided a framework and methodology for answering the following research questions:

- Do Australian primary principals use similar interventions when facilitating implementation of Computer Education?

- Do Australian primary principals demonstrate change facilitation styles of "responder", "manager" and "initiator" as suggested in North American and European studies?

- Is there a relationship between the change facilitation style of Australian primary principals and the degree of implementation of Computer Education by teachers?

To answer these questions, a longitudinal study over one year was undertaken of a group of selected Australian primary school principals, in one educational region, as Computer Education was introduced in their 
schools. This paper provides an overview of the procedure used, selected findings which resulted, and the types of interventions used by principals in implementing Computer Education.

\title{
Methodology
}

The study was conducted in three phases; a pilot study, the identification and selection of principals, and an in-depth study of six primary schools as Computer Education was implemented. The pilot study determined the appropriateness of the CBAM data-gathering techniques in Australian schools and demonstrated that the rationale for Change Facilitation Style and Interventions had face validity in a different cultural context, and when used for a different innovation (Schiller, 1985). To determine whether the change facilitation (CF) styles of responder, manager and initiator had face validity for Australian educators, composite descriptions of each style (Exhibit 1) were shown to a panel of 13 educational experts. Labels were removed from the descriptions to avoid panel bias. The experts were unanimous that the description of the three change facilitation styles were meaningful to them and that they could identify principals whose approach to change facilitation was covered by one of the descriptions. Each expert categorised 37 primary school principals, who had previously been identified as being in a school where Computer Education was a priority for implementation, according to the three $\mathrm{CF}$ styles. From the resulting matrix of choices, two principals were selected from each of the three categories, on the basis of agreement of over half the experts.

\section{Exhibit 1: Change Facilitation Style Descriptions}

\begin{abstract}
RESPONDERS place heavy emphasis on allowing teachers and others the opportunity to take the lead. They believe their primary role is to maintain a smooth running school by focussing on traditional administrative tasks, keeping teachers content and treating students well. Teachers are viewed as strong professionals who are able to carry out their instructional role with little guidance. They emphasise the personal side of their relationships with teachers and others. Before they make decisions they often give everyone an opportunity to have input so as to weigh their feelings or to allow others to make the decision. A related characteristic is the tendency toward making decisions in terms of immediate circumstances rather than in terms of longer range instructional or school goals. This seems to be due in part to their desire to please others and in part to their limited vision of how their school and staff should change in the future.
\end{abstract}

MANAGERS represent a broader range of behaviours. They demonstrate both responsive behaviours in answer to situations or people and they also initiate actions in support of the change effort. The variations in their 


\begin{abstract}
behaviour seem to be linked to their rapport with teachers and central office staff as well as how well they understand and buy into a particular change effort. They work without fanfare to provide basic support to facilitate teachers' use of the innovation. They keep teachers informed about decisions and are sensitive to teacher needs. They will defend their teachers from what are perceived as excessive demands. When they learn that the central office wants something to happen in their school they then become very involved with their teachers in making it happen. Yet, they do not typically initiate attempts to move beyond the basics of what is imposed.

INITIATORS have clear, decisive long-range policies and goals that transcend but include implementation of the current innovation. They tend to have very strong beliefs about what good schools and teaching should be like and work intensely to attain this vision. Decisions are made in relation to their goals for the school and in terms of what they believe to be best for students which is based on current knowledge of classroom practice. They have strong expectations for students, teachers and themselves. They convey and monitor these expectations through frequent contacts with teachers and clear explication of how the school is to operate and how teachers are to teach. When they feel it is in the best interest of their school, particularly the students, they will seek changes in district programs or policies or they will reinterpret them to suit the needs of the school. They will be adamant but not unkind, they solicit input from staff and then decisions are made in terms of the goal of the school even if some are ruffled by their directness and high expectations. (Hall, et al, 1984, p23-24).
\end{abstract}

Each of the six principals was given a package of materials providing an overview of the study, assurances regarding confidentiality, and instructions on how to compile intervention log sheets similar to those which had been used in the Principal-Teacher Interaction (PTI) study (Hall, Hord, Huling, Rutherford \& Stiegelbauer, 1983). An intervention is described as "... an action or event or set of actions or events that influence use of the innovation" (Hall \& Hord, 1984, p.283).

Intervention data were then gathered for twelve months using qualitative and quantitative documentation procedures including telephone calls, onsite interviews, document collection, field note taking and intervention logs maintained by each principal and selected staff (Schiller, 1988).

Implementation data were collected from teachers using established CBAM techniques (Marsh, 1986) which included Stages of Concern questionnaires (SoC), Levels of Use interviews (LoU), and Innovation Configuration (IC) interviews and checklists. The sequence of data collection and range of instruments used is shown in Table 1. 
Table 1: Data collection procedures and timeline

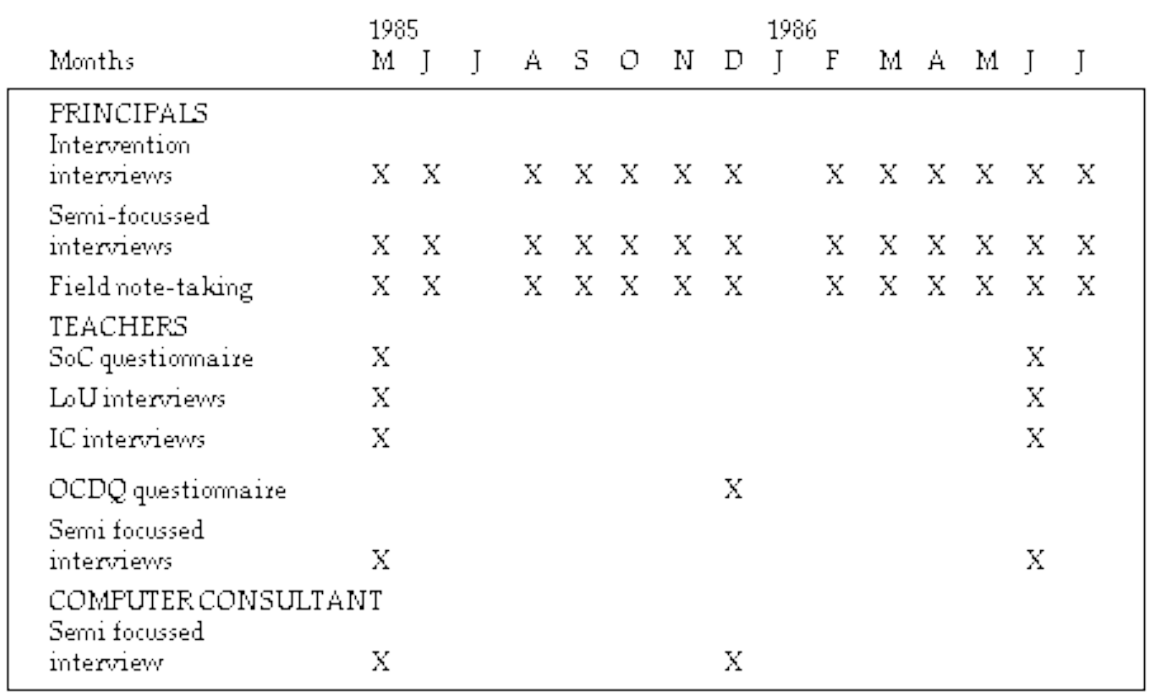

Although the procedures followed were intended to replicate those used in the PTI study, there were a number of important variations. First, all schools were in the same educational region of the state. Second, rather than bi-weekly telephone calls, each principal was interviewed regularly on a face-to-face basis (all interviews were audiotaped and transcribed). Third, the study period spanned two academic years so that the impact of annual staff turnover on implementation could be assessed. Fourth, the same innovation was examined at all schools. In contrast to the statemandated curriculum areas studied in the PTI study, the introduction of Computer Education in NSW primary schools was entirely determined at the school level. Finally, due to funding constraints, one researcher conducted all research. Although this restricted the scope of the data gathering, it increased internal consistency of data collection and analysis. The implementation data were coded and analysed using established procedures (Hall \& Hord, 1984,1987). The focus of this paper is the data related to interventions made by the principals in implementing Computer Education. 


\section{Results}

Although there was considerable activity relating to Computer Education at each school during the study period, there were marked variations among them as shown by the total number of interventions (see Table 2).

Table 2: Overall distribution of interventions (in actual counts)

\begin{tabular}{|lccccccc|}
\hline SCHOOL* & Wes & Hil & Val & P/S & Cen & Lak Average \\
Interventions & 58 & 100 & 157 & 145 & 142 & 185 & 131 \\
& & & & & & & \\
\hline
\end{tabular}

( ${ }^{*}$ Pseudonyms for the schools were Western, Hillside, Valley, Pacific, Southern, Central and Lakeview).

\section{Interventions used in the implementation of Computer Education}

The large number of interventions relating to Computer Education indicates that the process of implementation necessitates a great deal of day-to-day activity. The smallest level of intervention is called an incident intervention (Hall \& Hord, 1984, p.292), and includes brief interactions between individuals as well as single actions or events which influence use of an innovation. A major finding of the PTI study was that implementation success is related to the overall quantity of incident interventions (Hall \& Hord, 1987, p.172). Other studies of interventions in USA (Hougen, 1984; Trohoski, 1984) and Europe (Wylick, 1986; Vandenberghe, 1983), indicate similar findings. This poses a problem for NSW primary schools when multiple educational changes are introduced simultaneously. Computer Education is not the only priority at such schools. Other curriculum areas needed equal, if not greater, attention. For example, one principal identified ten curriculum changes and policy guidelines he and his staff had been expected to implement during the previous five years. As it proved impossible to implement all required changes, many were not implemented at the classroom level, although school policy statements indicated that the change had been adopted. Further, teacher interviews highlighted stress due to "innovation fatigue" (Schiller, 1988).

Exhibit 2: Anatomy of Interventions (Hord, Hall \& Zigarmi, 1980, p 7)

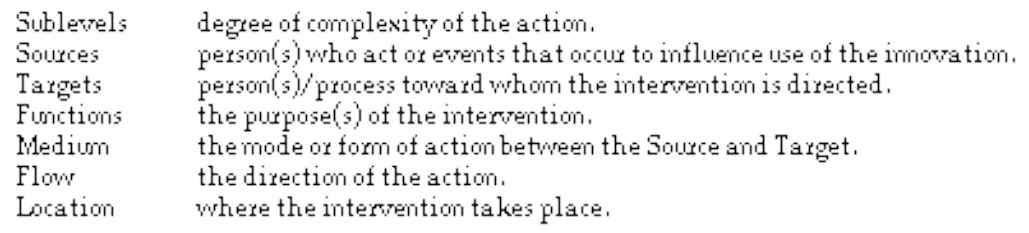


Each incident level intervention identified throughout the study was described separately. This enabled examination of the internal parts of each intervention (see Exhibit 2) as well as coding for analysis. Within each dimension, categories or "kinds" specify possible variations.

\section{Sources of incident interventions}

The percentage of incident interventions at each school, in terms of the persons who acted or events that occurred to influence use of Computer Education, is presented in Table 3. Neither the pupils, who were the clients, nor the teachers, who were the users, did much to initiate action. The higher proportion of 'individual users' as the source of an intervention, at Central and Lakeview Schools, was due to a school policy decision that every teacher would be involved in Computer Education. At the other schools, involvement was at the discretion of each teacher.

Table 3: All incident interventions by source (in percentages)

\begin{tabular}{|c|c|c|c|c|c|c|c|c|}
\hline Souxce & Wes & Hil & Val & $\mathrm{F} / \mathrm{S}$ & Cen & Lak & $\mathrm{Av}$ & Freq \\
\hline 1. Clients & 3 & & 1 & 1 & 1 & & 1 & 6 \\
\hline 2. An individual user & 5 & 1 & & 7 & 13 & 14 & 7 & 58 \\
\hline $\begin{array}{l}\text { 3A. Subset-as Individuals } \\
\text { 3E. Subset-as Groups } \\
\text { 3C. Subset-as Whole }\end{array}$ & & & & 1 & & & 1 & 1 \\
\hline $\begin{array}{l}\text { 4A. All Users-as Individuals } \\
\text { 4B. All Users-as Groups } \\
\text { 4C. All Users-as Whole }\end{array}$ & 3 & 1 & & 1 & 1 & $\begin{array}{l}2 \\
1 \\
1\end{array}$ & $\begin{array}{l}1 \\
1 \\
1\end{array}$ & $\begin{array}{l}3 \\
2 \\
7\end{array}$ \\
\hline \multicolumn{9}{|l|}{$\begin{array}{l}\text { 5. Implementation Site } \\
\text { Resource Feople }\end{array}$} \\
\hline $\begin{array}{l}\text { 6A. Frincipal } \\
6 \mathrm{~B} \text {. Assistant Frincipals } \\
6 \mathrm{C} \text {. Other (specify) }\end{array}$ & $\begin{array}{l}28 \\
28 \\
12\end{array}$ & $\begin{array}{l}37 \\
47\end{array}$ & $\begin{array}{r}15 \\
64 \\
3\end{array}$ & $\begin{array}{r}61 \\
2 \\
8\end{array}$ & 58 & $\begin{array}{r}57 \\
5\end{array}$ & $\begin{array}{r}45 \\
17 \\
9\end{array}$ & $\begin{array}{r}350 \\
180 \\
70\end{array}$ \\
\hline 7. Imovation Facilitator & 7 & & 3 & 1 & & 1 & 1 & 10 \\
\hline $\begin{array}{l}\text { 8A. I.U.S.-Decision Makers } \\
\text { 8E.I.U.S. -Resource Feople } \\
\text { 8C.I.U.S. -Other (specify) }\end{array}$ & 3 & 3 & 4 & 1 & 1 & 1 & 1 & 13 \\
\hline 9. Extended User System & 7 & 5 & 6 & 4 & 13 & 10 & 8 & 62 \\
\hline 10. Events & 3 & 3 & 3 & 8 & 3 & 5 & 4 & 34 \\
\hline $\begin{array}{l}\text { 11A. CBAM } \\
\text { 11B. Equipment }\end{array}$ & & 2 & 2 & 6 & 10 & 2 & 4 & 30 \\
\hline Total Number & 58 & 100 & 157 & 145 & 142 & 185 & & 787 \\
\hline
\end{tabular}


Implementation site decision makers (Category 6A, 6B, 6C) account for the greatest proportion of interventions at each school. Although this may be partly due to these individuals being the major sources of information about the interventions, this explanation does not account for the significant variation between schools. The higher percentage of interventions initiated by the principals will be discussed in a later section.

The assistant principals at Western and Valley Schools were responsible for a high proportion of interventions. Although each school had two assistant principals (one responsible for the Infant section, the other for the Primary section of the school), no pattern of interventions was evident except that only one of the assistant principals was active in Computer Education at a school at one time.

The combined interventions of the assistant principals at Valley school are markedly higher than in the other study schools. At Valley school the principal made it clear to his staff that he was willing to promote Computer Education but would leave the day-to-day responsibility for its implementation to the male assistant principal, who was most enthusiastic about developing a Computer Education program at the school. During the first half of the study, this assistant principal was responsible for $57 \%$ of all interventions at the school for the year as he worked with the school Computer Education Committee, the teachers, the parent committees and the principal; teaching, facilitating, encouraging, demonstrating and promoting Computer Education. When he was promoted to his own school at the end of the school year, mid-way through the study, implementation of Computer Education temporarily slowed down until the female assistant principal, with encouragement from the principal, decided to promote it further.

A similar pattern occurred at Hillside school except that a regular classroom teacher, with no administrative responsibility, became the promoter of Computer Education, interacting with the principal and a part-time teacher whose sole responsibility was to teach classes in Computer Education. He, too, was transferred to another school mid-way through the study but was responsible for $35 \%$ of all interventions. After his departure, Computer Education at Hillside School took several months to regain momentum as he was not replaced, due to the decline of student numbers.

The remaining variation in sources of intervention is in the so called miscellaneous (11B) category. Because of the emphasis on hardware in Computer Education, computers and printers became important sources of intervention. For example, equipment malfunction, due to inappropriate use and / or incorrect installation, markedly slowed the implementation process at Central School. 


\section{Degree of Implementation success of Computer Education}

The degree of teacher success in implementing Computer Education was determined by using a combination of Level of Use (LoU) data and Innovation Configuration (IC) data collected at each school during the twelve month study (Schiller, 1988).

The extent of Computer Education in an primary school and its major components (ie. its Innovation Configuration) were determined through interviews with users and classroom observation. In addition to the use of three types of computer at the six schools, there were major variations in teachers' use of Computer Education. First, their use varied according to the classroom location of the computer. In four schools, computers were located singly, either at the back of the classroom or in an adjacent storeroom. Two schools, Central and Hillside, had separate classrooms, designated for computer use. Second, in these separate computer classrooms, there were variations in innovation configuration. Computers were used as 'stand alones' or they were 'networked'. In a 'network', a master computer was operated through a number of linked terminals rather than operating as an independent (or 'stand alone') unit. Third, although the dominant method for teaching Computer Education was for the classroom teacher to teach it with occasional help from another staff member, Hillside staff made use of a part time computer teacher. Central School introduced this approach during the study.

Results indicate considerable variation between and within schools. Within a school, teacher implementation of Computer Education ranged from an occasional classroom discussion about computers, to students preparing classroom magazines using word processing packages. Between schools, variations in computer location and responsibility for teaching Computer Education were the most obvious.

Table 4: Rank order of schools according to implementation success of Computer Education

Greatest implementation success

\begin{tabular}{l}
\hline Lakeview \\
Central \\
Valley \\
Southern \\
Pacific \\
Hillside \\
Western \\
\hline Least implementation success
\end{tabular}


In summary, LoU and IC data reveal marked differences in the implementation success of Computer Education between study schools in the same educational region; despite similarities in number of students, staff composition and organisational structure. Schools were ranked in order of implementation success as shown in Table 4.

\section{The Role of the Principal in Computer Education}

To understand the role of principals in Computer Education, it is necessary to look at the interventions for which they were the source. As can be seen in Table 5, there were marked variations between schools in the proportion of principals' interventions. The principals of Pacific/Southern, Central, and Lakeview schools involved themselves in Computer Education, to a far greater extent than in the other schools. Analysis of interview transcripts showed that the principals of Western and Valley schools acknowledged that they left the promotion of Computer Education to other members of staff.

Table 5: Proportion of principals' interventions

\begin{tabular}{|lccc|}
\multicolumn{1}{c}{$\begin{array}{c}\text { Nomber of } \\
\text { Frincipal } \\
\text { School }\end{array}$} & $\begin{array}{c}\text { Total } \\
\text { Interventions }\end{array}$ & $\begin{array}{c}\text { Fercentage } \\
\text { of total }\end{array}$ \\
\hline Westem & 16 & 58 & 28 \\
Hillside & 37 & 100 & 37 \\
Valley & 24 & 157 & 15 \\
Facific/Southem & 88 & 145 & 61 \\
Central & 82 & 142 & 58 \\
Lakeview & 106 & 185 & 56 \\
& & & \\
Total & 353 & 787 & 45 \\
\hline
\end{tabular}

The principal of Hillside, however, saw himself as an active advocate of Computer Education, yet his interventions indicate relatively low involvement. Interview transcripts were also examined to determine whether principal's computer knowledge and skill could explain the differences in involvement. This provided a possible explanation for the lower number of interventions at Western, Hillside, and Valley schools as the principals of these schools professed to be 'computer illiterate'.

The lower proportion of interventions targeted at these two principals supports this explanation. However, the principal of Lakeview school, with the highest number of interventions, also claimed to be 'computer illiterate', so it was obvious that more detailed examination of the data was 
required. This was done through analysis of the components of each intervention.

\section{The target of Principal interventions}

The principals targeted their Computer Education related interventions toward a range of people within the school, as well as to the wider community, as shown in Table 6. They also intervened in the implementation process itself.

Table 6: Principal incident interventions by target (in percentages)

\begin{tabular}{|c|c|c|c|c|c|c|c|c|}
\hline Source & Wes & Hil & Wal & $\mathrm{F} / \mathrm{S}$ & Cen & Lak & Av & Freq \\
\hline 1. Clients & & & & 6 & 5 & 2 & 3 & 11 \\
\hline 2. An individual user & 6 & & & 9 & 4 & 9 & 6 & 22 \\
\hline $\begin{array}{l}\text { 3A. Subset-as Individuals } \\
\text { 3B. Subset-as Groups }\end{array}$ & 6 & & & 7 & & 7 & 4 & 14 \\
\hline 3C. Subset-as Whole & & & & 1 & & & 1 & 1 \\
\hline 4A. All Users-as Individuals & 6 & & 8 & 6 & 1 & 22 & 9 & 32 \\
\hline 4B. All Users-as Groups & 6 & & 8 & & 5 & 9 & 5 & 16 \\
\hline 4C. All Users-as Whole & 13 & 5 & 8 & 2 & 7 & 7 & 6 & 21 \\
\hline $\begin{array}{l}\text { 5. Implementation Site } \\
\text { Resoure Feople }\end{array}$ & 6 & & & 1 & & 2 & 1 & 4 \\
\hline $\begin{array}{l}\text { 6A. Frincipal } \\
6 \mathrm{~B} \text {. Assistant Frincipals } \\
6 \mathrm{C} \text {. Other (specify) }\end{array}$ & 19 & $\begin{array}{r}3 \\
60\end{array}$ & 38 & $\begin{array}{l}7 \\
2\end{array}$ & 9 & $\begin{array}{l}4 \\
5\end{array}$ & $\begin{array}{r}6 \\
11\end{array}$ & $\begin{array}{l}20 \\
40\end{array}$ \\
\hline 7. Imovation Facilitator & 25 & 8 & & 7 & 6 & 6 & 7 & 24 \\
\hline $\begin{array}{l}\text { 8A. I.U.S.-Decision Makers } \\
\text { 8B , I.U.S. -Resource Feople }\end{array}$ & & & & & 1 & 2 & 1 & 3 \\
\hline 8C . I.U.S. -Other (specify) & & 3 & 13 & 1 & 4 & 1 & 3 & 9 \\
\hline 9. Extended User System & & 14 & 17 & 18 & 34 & 18 & 20 & 72 \\
\hline 10. Events & 13 & 8 & 4 & 14 & 10 & 7 & 9 & 33 \\
\hline $\begin{array}{l}\text { 11A. CBAM } \\
\text { 11B. Equipment }\end{array}$ & & & & 19 & 13 & 2 & 9 & 33 \\
\hline Total Number & 16 & 37 & 24 & 88 & 82 & 106 & & 358 \\
\hline
\end{tabular}

The table highlights the following:

- The principal at Lakeview School targeted a greater proportion of her interventions to members of her staff; working with them on a one to one basis, whereas the principal of Hillside interacted with potential users of Computer Education as a whole staff group.

- The assistant principals at Valley School were targeted markedly more times by their principal than at any of the other study schools. During 
the first half of the study period, the assistant principal responsible for the senior grades was the main change facilitator for Computer Education. Interaction with the principal was to discuss implementation progress. After his transfer to another school, the principal encouraged his replacement to become the major change facilitator. Although this did not occur, the assistant principal responsible for the junior grades took up this role and therefore continued to be a target of the principal's interventions.

- Similarly, a senior teacher at Hillside School was the main change facilitator of Computer Education, as his principal, like the principal at Valley School, knew little about the operation of computers. This accounts for the high proportion of interventions targeted to 'other' at Hillside as the principal sought advice and information from the school 'computer expert'.

- The local computer company, as one of the elements of the 'extended user system', was the target of many of the principal's interventions at Central School as he tried to rectify electronic problems in the networked system of linked computers. At Pacific/Southern and Central Schools, the computer equipment was the target of many principal interventions. In both schools, the principal was the school computer 'expert' and subsequently spent time monitoring, maintaining and repairing the equipment.

- Although several other targets appear to be significant, the low frequency of the interventions renders them inconsequential in terms of the overall pattern of principal interventions. This was confirmed by analysis of the individual interventions.

In summary, the data show marked variations in the target of the principal's interventions. Within the study schools, the major targets were the teachers, as potential or actual users of Computer Education, other school change facilitators or the computer equipment itself . Beyond the school, the computer company was the major recipient of the principals' interventions.

To understand the role of principals in implementing Computer Education, it is necessary to know the purpose of their interventions. This is the subject of the next section.

\section{The functions of Principal interventions}

'Developing supportive or organisational arrangements and resource acquisition', was the main purpose for principal intervention, as shown in Table 7, accounting for $50 \%$ to $79 \%$ of all subject principals' interventions. 
Table 7: Principal incident interventions by function (in percentages)

\begin{tabular}{|c|c|c|c|c|c|c|c|c|}
\hline \multirow[b]{2}{*}{ Function } & \multicolumn{8}{|c|}{ Schools } \\
\hline & Wes & Hil & Val & $\mathrm{F} / \mathrm{S}$ & Cen & Lak & $\mathrm{Av}$ & Freg \\
\hline $\begin{array}{l}\text { 1000. Developing Supp/ } \\
\text { Oxg. Arrangements }\end{array}$ & 69 & 70 & 79 & 52 & 61 & 50 & 57 & 201 \\
\hline 2000 . Training & & & & 14 & 8 & & 8 & 19 \\
\hline $\begin{array}{l}\text { 3000. Consulting and } \\
\text { Reinforcing }\end{array}$ & 13 & 16 & 8 & 8 & 12 & 18 & 13 & 46 \\
\hline 4000. Monitoring & 6 & 16 & 8 & 19 & 11 & 26 & 15 & 58 \\
\hline 5000. Communicating Ext. & & & 4 & 1 & 2 & 1 & 1 & 5 \\
\hline 6000 . Disseminating & & & & 2 & 2 & 2 & 2 & 6 \\
\hline 7000 . Impeding Use & & & & & & & & \\
\hline $\begin{array}{l}8000 . \text { Expressing/ } \\
\text { Resp to Concems }\end{array}$ & 6 & 3 & & 3 & 2 & 3 & 3 & 10 \\
\hline 9000. Other (specify) & 6 & 5 & & & & & 1 & 3 \\
\hline Total Number & 16 & 37 & 24 & 88 & 82 & 106 & & 353 \\
\hline
\end{tabular}

Within this category, a subsection 'seeking or providing materials, information, space, and other resources' was the major emphasis at four of the study schools; Valley, Pacific/Southern, Central, and Lakeview, where $24-33 \%$ of the principal's interventions were for this purpose. The principals of Western and Hillside schools, however, spent proportionately more time on interventions which involved planning.

Interventions of three subject principals were related to ensuring that the equipment was secure and working properly. At Central and Pacific/ Southern this also involved the principals in equipment maintenance as they had the required skills. These two principals were the only ones who intervened for the purpose of teaching new knowledge and skills or to review or clarify aspects of Computer Education. As they were the 'resident experts' they were able to help their staff in ways different from the other principals.

The intervention functions of 'consulting and reinforcing', which helped to promote implementation of Computer Education, were used by each of the subject principals. The principal at Lakeview recorded the highest proportion in this category. Her main strategy for accomplishing this was to visit classrooms to watch and talk with teachers and students as they worked with computers. She also used these classroom visits to 'monitor and evaluate' the implementation process. Inspection of teacher's planning documents and subsequent individual discussion were also used by her to monitor each teacher's implementation intentions and actions. This 
resulted in a significantly higher proportion of interventions in this category. The principal of Hillside also monitored teacher's planning material, but only with the part time teacher who looked after the computer room.

The principal of Pacific/Southern Schools was the only principal to record interventions in which periodic checks were carried out to ensure that all equipment was operating correctly. Teachers stated that the principal of Central School also monitored equipment operation during many brief visits to the computer room next to his office. Because he did not record these visits in his intervention log, or mention them in interview, they do not appear as part of the data.

The proportion of interventions in the remaining function categories was low. No major variations between schools was found in the data. This result replicates that of the PTI study, namely, that implementation success is greater when principals intervened across each of the first four categories. Lack of intervention in one of these areas was associated with reduced implementation success.

Because marked variations existed between the study schools in terms of implementation success, and that there were marked variations between the interventions used by the subject principals, the next focus is the relationship between the change facilitation styles of the study principals and implementation success.

\section{Relationship between change facilitation style and implementation success}

\section{Principals who let it happen}

In implementing Computer Education, the principals of Western, Hillside and Valley schools exhibited a Responder change facilitation (CF) style (Hall, Rutherford, Hord \& Huling, 1984). This corresponded to the CF style categories in which they had been placed by the panel of experts, although the principal of Valley school had been expected to exhibit more characteristics of a Manager CF style. These three principals emphasised the present situation in terms of Computer Education. Although they each stated that Computer Education was a high priority for implementation in their schools, the lower proportion of their interventions and the narrower range of their targets, indicated to their staffs that their commitment to Computer Education tended to rely on words rather than actions.

The principals of Western and Hillside Schools chose not to become personally involved in Computer Education, leaving the promotion and implementation of it to either one of their assistant principals or to an 
enthusiastic teacher. The principal at Hillside regarded Computer Education as an important innovation but limited his involvement to discussions with the part-time Computer Education teacher or the senior teacher who were its main promoters. When this teacher was transferred mid-way through the study, another senior class teacher was appointed, by the principal, as the person in charge of Computer Education, but no action was taken by the principal to facilitate this person carrying out their tasks.

The principal of Hillside, along with the principals of Valley and Western schools relied on members of their staff to initiate and help the other members of staff in the implementation process. The three principals acknowledged their lack of knowledge and skills regarding Computer Education but took no steps to change this. They depended on others within the school to take action and facilitate change. They encouraged members of staff to become involved but left the staff to make their own decisions as to how they would go about it. These principals also highlighted, in interview, the difficulties they were having in coping with changes expected of them by parents, children, teachers and the State Education authorities. The principal at Western emphasised these additional pressures during every interview, despite attempts to concentrate on issues relating to Computer Education. His frustration at his inability to respond to the pressures for change, resulted in his early retirement shortly after the conclusion of the study.

Neither of the other two principals, who demonstrated a Responder CF style, observed their teachers implementing Computer Education. Their teachers indicated, during interview, that they felt that their principals were only mildly interested in the promotion of Computer Education. Essentially, these three principals "let Computer Education happen". They allowed their teachers to implement it if they wanted to, they were supportive of staff members who wanted to promote it, they helped in the implementation process when asked, but their overall reaction to Computer Education was to respond to the initiative of others.

\section{Principals who help it happen}

In contrast to this approach, the principals at Pacific/Southern, Central and Lakeview Schools were actively involved in Computer Education; participating, encouraging, and promoting it by their words and actions. At Pacific School, the principal, assistant principal and a senior grade teacher were the major facilitators of Computer Education. Together, they prepared funding submissions to acquire the computer hardware and software. The principal saw himself as the person who was responsible for ensuring that any teacher, who wanted to implement computer Education, was provided with the resources to do it. His approach to leading the staff in implementing Computer Education was that of a manager, in that he 
demonstrated a Manager CF style. He organised parents to help prepare resources, he obtained advice and help from the Computer consultant, and he arranged for a local computer users group to use the school and its computing facilities for its monthly meetings. By doing this, he could learn more about computers and thereby be better equipped to support the staff in their usage. He spent time during his holidays completing the funding submission after he had obtained input from all staff and spent long hours ensuring that resources and supplies for Computer Education were available. Regular checks were made to ensure that all the equipment was operational.

His intervention log showed his attention to detail in that entries were maintained on a daily basis and meticulously documented. As one of the school's 'computer experts', he made himself available to assist any teacher who requested help. However, he did not promote usage of Computer Education if a teacher was reluctant. For example, he accepted the decision of the junior grade teachers to return their computer and discontinue involvement with Computer Education because they had decided on other curriculum priorities. After his transfer to Southern School he continued exhibiting a Manager CF style by helping any teacher who asked, by ensuring that teachers had easy access to equipment and resources, and by taking a teacher's class for an hour a week so that the teacher, a keen computer user, could become the school's computer consultant and help teachers implement Computer Education.

As principal of Pacific and then Southern school, he assisted in the development of an overall school policy on Computer Education which structured the implementation process and gave it direction. Although not the formulator of the policy, he was an active participant in its development and helped consolidate and refine it as a member of the school team promoting Computer Education.

\section{Principals who make it happen}

The development of a Computer Education policy at Valley School was undertaken by the assistant principal, who was the main advocate of computer usage. He prepared a comprehensive policy based on input from many sources and then presented it in draft form to the principal for endorsement. This assistant principal knew what he wanted in terms of Computer Education at Valley school and devised a long-term strategy to accomplish it. When a group of parents intervened to vary the approach, he was able to manipulate the situation for the long-term benefit of the program because he had an overall vision of how Computer Education could develop at Valley School. This was in contrast to his principal's approach to Computer Education, and to the approach taken by the 
principals of Western, Hillside, and Pacific/ Southern, who did not appear to have a vision of what they wanted Computer Education to become at their schools.

Although the program faltered temporarily after his promotion and subsequent transfer as principal to another school, the impetus and structure he had provided, ensured that Computer Education continued, despite minimal involvement of the principal.

Being able to see how to develop and implement Computer Education characterised the change facilitation style of this assistant principal and the principals of Central and Lakeview schools. They were able to single handedly devise long-term goals and implementation strategies for Computer Education, and to work out specific day-to-day tactics to accomplish them. They facilitated staff decisions to accept Computer Education as a priority, and then ensured that all staff met their obligations. They used an Initiator CF style in implementing Computer Education.

Although Computer Education was a voluntary area for implementation by individual teachers in other schools, the principals of Central and Lakeview schools expected every teacher to become a user of it. They stressed it during staff meetings, they organised staff training, they ensured adequate time and resources were available, and they monitored and checked every teacher's progress in it by looking at their programs and other written materials.

These principals also spent time in the classrooms, observing and talking with pupils and teachers as they used the computers. They initiated and encouraged staff participation in the implementation process through regular staff discussion. They actively sought parental involvement and support through parent workshops and meetings.

\section{Coping with the unexpected}

The ways in which they coped with unexpected and unanticipated events, termed "mushrooms" ( Hall \& Hord, 1984) varied between the six principals. The Responder CF style principals of Western, Hillside and Valley schools took no action when equipment malfunction occurred, leaving it to other staff to repair, whereas the principals of Central, Lakeview or Pacific/Southern, either repaired it themselves, or immediately arranged for something to be done. At Western, many interruptions and unexpected events, such as staff transfer, changes in government priorities, and changes in funding accumulated without action being taken. Their combined pressure prompted the principal's early retirement. At Hillside, numerous extended absences from the school, due to long service leave by the principal, coupled with a lack of 
regular consultation and shared decision-making with teachers, caused staff unrest, necessitating the intervention of a regional management team.

Rather than allowing mushrooms to develop, the principals of the other schools intervened when the unexpected occurred. Equipment malfunction, because of the vagaries of a networked system at Central School, resulted in the principal attempting repairs himself, calling in the computer company representative and, eventually, negotiating for an updated system. When staff were transferred at schools, where the principal used either a Manager or an Initiator CF style, new staff were inducted into Computer Education as quickly as possible, by provision of training and resources. Similarly, changes in funding resulted in these principals re-ordering school priorities or seeking alternative sources of funding. On the other hand, in schools led by Responder CF style principals, very little action was taken to counter the unexpected. Equipment malfunction was left to another staff member to rectify. New staff were not inducted into the schools' Computer Education program and changes in government priorities and funding arrangements were accepted as inevitable problems.

In summary, there was a relationship between the change facilitation style of the principal and implementation success, with greatest success occurring in schools where principals exhibited an Initiator CF style. They "made Computer Education happen" rather than "let it" or "helped it happen". Less progress in implementation took place in schools led by principals who demonstrated a Responder CF style in terms of Computer Education, despite attempts by the second change facilitator to influence implementation. There was also a relationship between the number of interventions by the principal and implementation success of Computer Education, as indicated by teachers' Levels of Use and Innovation Configuration. More interventions were associated with greater success in implementation and Manager or Initiator CF styles of principal leadership.

\section{Conclusion}

The results of this study replicate those of Hall and Hord (1987) in the following ways. First, this group of NSW primary school principals demonstrated Responder, Manager and Initiator CF styles in implementing an innovation. Second, a relationship between change facilitation style of school leaders and implementation success of school change was substantiated. Third, although unplanned interruptions were more frequent than those in the Hall and Hord study, principals who exhibited an Initiator $\mathrm{CF}$ style took more positive actions to cope with these interruptions. Finally, within each school, at least one other member of staff adopted a change facilitation role. The reality is that the primary school principal can be an agent of change but that he or she does not carry out this role single-handedly. 
The Principal Teacher Interaction study constructs applied even though the cultural setting differs, the nature, type and origin of the innovation is different, and the administrative structure of Australian primary schools operates in a different way from primary schools in North America.

\section{References}

Anderson, J. (1984). Computing in schools: An Australian perspective. Australian Education Review, 21.

Baume, G., Keepes, B., Marsland, L., Rosen, B., Russell, L., Taplin, R., \& Van Groen, G. (1986). Computers across the curriculum. (A TEASA Research Project Interim Report). South Australian College of Advanced Education.

Bossert, S. T., Dwyer, D. C., Rowan, B., \& Lee, G. V. (1982, Summer). The instructional management role of the principal. Educational Administration Quarterly, 18(3), 34-64.

Carbines, R. J. (1986, April). The relationship between the degree of implementation of computers for use in learning in the Primary school and selected characteristics of the school: Organizational climate and strategies used for implementation. Unpublished Ph.D. Thesis, University of New England.

Commonwealth Schools Commission. (1984). Teaching, learning and computers: 1984 Information Kit. Canberra: Commonwealth Schools Commission.

Duke, D. L. (1987). School leadership and instructional improvement. New York: Random House.

Duignan, P. (1984, August). The Role and professional development of Australian school principals. Paper presented at the 11th National Conference of the Australian Council for Educational Administration, Canberra.

Fitzgerald, D., Hattie, J., \& Hughes, P. (1985). Computer applications in Australian classrooms. Canberra: Australian Government Publishing Service.

Fullan, M. (1982). The meaning of educational change. Toronto: Ontario Institute for Studies in Education.

Hall, G. E., \& Hord, S. M. (1987). Change in schools: Facilitating the process. New York: State University of New York Press.

Hall, G. E., \& Hord, S. M. (1984). Analysing what change facilitators do: The intervention taxonomy. Knowledge Creation, Diffusion, Utilization, 5(3), 275-307.

Hall, G. E., Hord, S. M., Huling, L. L., Rutherford, W. L. \& Stiegelbauer, S. M. (1983). Leadership variables associated with successful school improvement. Symposium presented at the annual meeting of the American Educational Research Association. Montreal, Canada. 
Hall, G. E., Loucks, S. F., Rutherford, W. L., \& Newlove, B. W. (1975, Spring). Levels of use of an innovation: A framework for analyzing innovation adoption. Journal of Teacher Education, 26(1), 52-56.

Hall, G., Rutherford, W., Hord, 5., \& Huling, L. (1984, February). Effects of three principal styles on school improvement. Educational Leadership, 41(5), 22-29.

Hallinger, P., \& Murphy, J. (1985, November). Assessing the instructional management behaviour of principals. The Elementary School Journal, 86(2).

Hord, S., Hall, G. E., \& Zigarmi, P. (1980, April). Anatomy of incident and tactic interventions: Dimensions, design. Paper presented at the annual meeting of the American Educational Research Association, Boston.

Hord, S. M., \& Huling-Austin, L. (1986). Effective curriculum implementation: Some promising new insights. The Elementary School Journal, 87(1).

Hougen, M. C. (1984). High school principals: An analysis of their approach to facilitating implementation of microcomputers. Unpublished Ph.D. Thesis, University of Texas, Austin.

Kmetz, J. T., \& Willower, D. J. (1982, Fall). Elementary school principals' work behaviour. Educational Administration Quarterly, 18(4), 62-78.

Leithwood, K. A., \& Montgomery, D. J. (1982, Fall). The role of the elementary school principal in program improvement. Review of Educational Research, 52(3), 309-339.

MacKay, G. (1983, November). Introducing the computer to the primary school. Paper presented at Australian Association for Research in Education, Canberra.

Marsh, C. J. (1986). Curriculum Implementation: An analysis of Australian research studies, 1973-1983. Curriculum Perspectives, 6(1).

Morris, V. C., Crowson, R. L., Porter-Gehre, C., \& Hurwitz, E. (1984). Principal in action: the reality of managing schools. Columbus, Ohio: Charles E. Merrill.

Peterson, K. D. (1978). The Principal's task. Administrator's Notebook, 27(3), 14.

Persell, C. H. \& Cookson, P. W. J. (1982). The effective principal in action. In The effective principal: A research summary. Reston, VA: National Association of Secondary School Principals. (pp.22-29).

Purkey, S. C., \& Smith, M. S. (1983). Effective schools: A review. The Elementary School Journal, 83(4).

Schiller, J. (1988). The primary school principal as an agent of change: the relationship between principal interventions and teacher implementation of Computer Education. Unpublished PhD Thesis, University of Newcastle, NSW.

Schiller, J. (1985, July). The change facilitator styles of primary principals and their effects on teacher implementation of a new curriculum: Preliminary findings. A paper presented at the 15th annual conference of the South Pacific Association for Teacher Education, Hobart, Tas. 
Trohoski, C. G. (1984). Principals interventions in the implementation of a school health program. Unpublished PhD Thesis, University of Pennsylvania.

Willis, Q. (1980, July). The work activity of school principals: An observational study. Journal of Educational Administration, 18(1).

Vandenberghe, R. (1983, April). Studying change in primary and secondary schools in Belgium and the Netherlands. Paper presented at American Educational Research Association, Montreal.

van Wijlick, W. G. (1987). The activities of internal change facilitators: An analysis of interventions. In R. Vandenberghe and G. E. Hall (eds). Research on Internal Change Facilitation in Schools. Leuven, Belgium: ACCO (Academic Publishing Company).

Author: Dr John Schiller is the Director of Off-campus studies at the University of Newcastle, NSW. His role includes assisting lecturers develop alternative methods for teaching in both off campus and on-campus settings. He has been a primary and secondary teacher in South Australia and Alberta, Canada, an elementary school principal in Alberta, and a lecturer in teaching methodology at the Newcastle College of Advanced Education, Newcastle, NSW. His major research interest is the implementation and management of educational change.

Please cite as: Schiller, J. (1991). Implementing computer education: The role of the primary principal. Australian Journal of Educational Technology, 7(1), 48-69. http: / / www.ascilite.org.au / ajet/ajet7 / schiller.html 